Для розв'язання напрямів подальшого розвитку змісту передшкільної освіти в Україні необхідно виявити тенденції як ті, що були провідними у минулому столітті, так і ті, що виявляються в сучасному змісті дошкільної, передшкільної і початкової освіти, оскільки вони $є$ орієнтиром моделювання змісту системи передшкільної освіти в сучасному освітньому просторі, тобто тенденції, зумовлені вимогами часу і згодом можуть стати інноваційним напрямом розвитку загальної перед шкільної освіти.

Виклики XXI століття й ті цивілізаційні зміни, що нині відбуваються, вимагають окреслення нових завдань та визначення перспективних тенденцій модернізації і подальших трансформацій насамперед загального змісту освіти. Провідними тенденціями оновлення світового освітнього простору на сучасному етапі $є$ : орієнтація більшості країн на перехід від елітної освіти до високоякісної освіти для всіх; поглиблення міждержавного співробітництва у галузях освіти, яке залежить від потенціалу національної системи освіти і від рівня умов партнерства держави і окремих учасників; розширення гуманітарного складника у світовій освіті в цілому за рахунок уведення людиноорієнтованих наукових і навчальних дисциплін; значне поширення нововведень за умов збереження національних традицій, що склалися, та національної ідентичності країн і регіонів [5, с. 190].

Отже, відповідно до означених актуальних напрямів розбудови системи дошкільної освіти в Україні [1, с. 130], ми визначили провідні тенденції модернізації і подальших трансформацій змісту перед шкільної освіти як проміжної ланки між дошкільною і початковою освітою. Серед найбільш головних і перспективних тенденцій окреслимо такі: стандартизація змісту передшкільної освіти; орієнтація змісту перед шкільної освіти на реалізацію принципу дитиноцентризму; орієнтація на компетентнісну парадигму передшкільної освіти; всеохопленість дітей перед шкільного віку їх перебування у навчальних закладах різного типу; варіативність програм і методик передшкільної освіти.

\title{
Література
}

1. Біла книга національної освіти України / за ред. В. Г.Кременя. - К. : ТОВ «Інформаційні системи», 2010. - 342 с. 2. Курило В. С. Становлення і розвиток системи освіти та педагогічної думки східноукраїнського регіону в XX столітті: дис. доктора пед. наук: 13.00 .01 / Курило В. С. Луганськ, 2000. - 477 с. 3. Лист МОН України «Про організацію короткотривалого перебування дітей у дошкільних навчальних закладах» №1/9-431 від 17.08.2005 р. [Електронний ресурс]. Режим доступу: htt: // www.yur-info. org. da / doc / jsp /. 4. Авдюгіна К. Про підготовку дітей до навчання в школі / К. Авдюгіна // Дошкільне виховання. - К. : Рад. школа, 1959. - №12. - С. 10-13. 5. Педагогіка вищої школи : [навч. посіб.] / 3. Н. Курлянд, Р. І. Хмелюк, А. В. Семенова та ін.. Одеса : ПДПУ ім. К. Д.Ушинського, 2002. - 344 с.

УДК 378:37.011.33

Г. В. Хімрова, аспірант,

РВНЗ «Кримський гуманітарний університет» (м. Ялта)

\section{РЕАЛІЗАЦІЯ ТЕХНОЛОГІЇ ГРОМАДЯНСЬКОГО ВИХОВАННЯ СТУДЕНТІВ У НАВЧАЛЬНО-ВИХОВНОМУ ПРОЦЕСІ ВНЗ}

Хітрова Г. В. Реалізація технології громадянського виховання студентів у навчально-виховному процесі ВНЗ.

У статті розкрито сутність і зміст технології громадянського виховання студентської молоді в навчально-виховному процесі вищого навчального закладу. Визначено ключові етапи та напрями діяльності суб’єктів вищої школи. Наведено приклади використання форм і методів формування громадянськості студентів.

Ключові слова: технологія, технологія громадянського виховання, навчально-виховний процес.

Хитрова А. В. Реализация технологии гражданского воспитания студентов в учебновоспитательном процессе вуза.

В статье раскрыто сущность и содержание технологии гражданского воспитания студенческой молодежи в учебно-воспитательном процессе высшего учебного заведения. Определены ключевые 
этапы и направления деятельности субъектов высшей школы. Приведены примеры использования форм и методов формирования гражданственности студентов.

Ключевые слова: технология, технология гражданского воспитания, учебно-воспитательный процесс.

Khitrova A. V. Realization of technologies of civil education of students in a educate process in higher education.

The article reveals the essence of technology and content of civic education of students in the educational process in higher education. The key stages and directions activity of subjects of higher school are certain. The examples of the use of forms and methods of forming of civic of students are resulted.

Key words: technology, technology civic education, the educational process.

Усталення особистісно-гуманістичної парадигми виховання, усвідомлення специфічної ролі періоду професійного навчання в процесах особистісної самореалізації, професійної та громадянської ідентифікації студентської молоді зумовлюють важливе значення технологічної компоненти в системі вищої освіти. Технологізація навчально-виховного процесу здійснюється шляхом упровадження конкретної технології. Технологія громадянського виховання студентів відповідає основним принципам формування громадянськості й розкриває зміст виховної й позааудиторної діяльності викладачів ВНЗ.

Аналіз психолого-педагогічної літератури (I. Бех, М. Боришевський, П. Ігнатенко, Ю. Завалевський, Н. Косарєва, Л. Крицька, В. Поплужний, О. Сухомлинська) [1; 2] i дисертаційних робіт із проблем громадянського виховання та формування громадянськості студентської молоді (О. Кафарська, І. Пацора, Н. Савелюк, Н. Савотіна, А. Сігова, І. Сопівник) [5; 6] свідчить про те, що нині активізується дослідження цієї проблеми, яку висвітлено в серіях науково-популярних видань, у педагогічній i методичній періодиці. Збільшення кількості робіт, присвячених питанням формування громадянськості студентської молоді, свідчить про пильну увагу вчених до цього питання. Водночас питання про технологію громадянського виховання студентів вищих навчальних закладів вивчене недостатньо, що зумовлює актуальність нашого дослідження.

Mema cmammi - розкрити зміст та сутність реалізації технології громадянського виховання студентів у навчально-виховному процесі вищої школи.

Слово «технологія» походить від грецьких «techne»- поняття, вчення i «logos»майстерність, мистецтво [3, с. 123]. У широкому значенні технологію розуміють як сукупність знань про засоби здійснення процесів, за яких відбувається якісна зміна об'єкта. Базуючись на наявних у педагогічної науці поняттях системного підходу до виховання, педагогічними технологіями доречно вважати інструментарій досягнення цілей [3, с. 123].

Термін «технологія» у педагогіку ввів А. Макаренко. Він уважав, що справжній розвиток педагогічної науки пов'язаний із iï здатністю «проектувати особистість», тобто чітко передбачати ті ii якості і властивості, які мають сформуватися у процесі виховання. Визначеність цілей дає можливість перейти до чіткої технології виховання. Так, А. Макаренко зазначав: «Я під цілями виховання розумію програму людської особистості, програму людського характеру... Я вважаю, що ми, педагоги, повинні мати таку програму людської особистості, до якої необхідно прагнути» [3, с. 124].

Технологія виховання - це строго обгрунтована система педагогічних засобів, форм, методів, їх етапність, націленість на розв'язання конкретного виховного завдання. Кожне завдання має адекватну технологію виховання. Зміна завдання зумовлює зміну технології.

Отже, визначаємо сутність поняття технологія громадянського виховання - це логічно продумана система виховної роботи у вищій школі, що розв'язує завдання з формування громадянськості студентської молоді. 
В основі технології громадянського виховання покладено принципи реалізації навчально-виховного процесу ВНЗ, у площині якого здійснюється виховна й позааудиторна діяльність викладачів і кураторів академічних груп як головних суб'єктів, які актуалізують виховний процес у вищій школі.

Основними етапами технології $\epsilon$ : інформаційний, діяльнісно-продуктивний та рефлексивний, кожному з яких відповідають напрями роботи: цільовий, змістовий та організаційно-методичний.

Більш детально розкриємо взаємозв'язок між етапами та напрямам роботи технології громадянського виховання у табл. 1.

Таблиия 1.

Взаємозв'язок етапів та напрямів роботи технології громадянського виховання студентської молоді

\begin{tabular}{|c|c|c|c|}
\hline $\begin{array}{c}\text { Напрями роботи } \\
\text { / етапи }\end{array}$ & Інформаційний & $\begin{array}{c}\text { Діяльнісно- } \\
\text { продуктивний }\end{array}$ & Рефлексивний \\
\hline Цільовий & $\begin{array}{l}\text { Ознайомлення } \\
\text { основними } \\
\text { аспектами } \\
\text { громадянське } \\
\text { виховання, } \\
\text { структурою } \\
\text { громадянськості } \\
\end{array}$ & $\begin{array}{l}\text { Залучення } \\
\text { студентської молоді } \\
\text { до активної, } \\
\text { продуктивної } \\
\text { діяльності } \\
\text { громадянського } \\
\text { виховання }\end{array}$ & $\begin{array}{lr}\text { Залучення } & \text { молоді } \\
\text { самостійної } & \text { роботи, } \\
\text { самоаналізу } & \text { й } \\
\text { самовизначення } & \end{array}$ \\
\hline Змістовий & $\begin{array}{l}\text { 1) бесіди; } \\
\text { 2) робота } \\
\text { періодикою, } \\
\text { методичними } \\
\text { посібниками; } \\
\text { 3) упровадження } \\
\text { спецкурсу } \\
\text { громадянського } \\
\text { виховання }\end{array}$ & $\begin{array}{l}\text { 1) ділова гра; } \\
\text { 2) упровадження } \\
\text { практикумів; } \\
\text { 3) проведення } \\
\text { кураторських годин; } \\
\text { 4) організація та } \\
\text { проведення виховних } \\
\text { заходів }\end{array}$ & $\begin{array}{l}\text { 1) диспут; } \\
\text { 2) мозкова атака; } \\
\text { 3) створення та розв’язання } \\
\text { проблемних ситуацій; } \\
\text { 4) проектна діяльність }\end{array}$ \\
\hline $\begin{array}{c}\text { Організаційно- } \\
\text { методичний }\end{array}$ & $\begin{array}{l}\text { Ознайомлення } \\
\text { нормативно- } \\
\text { законодавчою базою }\end{array}$ & $\begin{array}{l}\text { Розроблення } \\
\text { реалізація } \\
\text { рекомендацій } \quad \text { ща щодо } \\
\text { організації } \\
\text { громадянського } \\
\text { виховання у ВНЗ }\end{array}$ & $\begin{array}{l}\text { Позааудиторна громадська } \\
\text { діяльність, участь у роботі } \\
\text { органів студентського } \\
\text { самоврядування, } \\
\text { розроблення та реалізація } \\
\text { планів виховної роботи у } \\
\text { ВНЗ }\end{array}$ \\
\hline
\end{tabular}

Інформаційний етап спрямовано на ознайомлення з теоретичними засадами та змістом громадянської освіти, що визначає основи громадянського виховання. Ця робота проводиться у відповідності з планом виховної діяльності куратора групи за допомогою таких форм і методів як упровадження спецкурсу, бесід та опрацювання матеріалів періодики, методичних посібників. Наведемо тематику проведення бесід із громадянського виховання зі студентами вищих навчальних закладів. «Громадянська освіта молоді та політика держави: шляхи реалізації й результати взаємодії», «Демократичні процеси у вищій школі: погляд студенської молоді», «Студентське самоврядування та політичне життя української держави», «Виборчий процес і сучасна молодь».

Діяльнісно-продуктивний етап визначає напрями роботи суб'єктів навчальновиховного процесу вищої школи із залучення студентської молоді до активної, продуктивної діяльності. Це здійснюється у формі ділової гри, впровадження практикумів, проведення кураторських годин, організації виховних заходів. Характерними особливостями ділової гри є: системний зміст навчального матеріалу, відтворення структури певної діяльності в ігровій навчальній моделі, наближення обстановки навчального процесу до реальних умов. Відповідно до цих особливостей визначають 
розвивальну, комунікативну, активізаційну й інформаційну функції навчальної ділової гри $[4$, c. 56]. Задля формування громадянськості студентам можна запропонувати такі теми для проведення навчальної ділової гри: «Державний устрій: реалії сьогодення з поглядом у майбутнє», «Українське суспільство очима молоді», «Громадянин України: сучасна модель».

Упровадження практикумів - це одна 3 форм проведення занять 3 громадянського виховання. Передусім вони спрямовані на практичне засвоєння теоретичних знань, здобутих під час колективного або самостійного опрацювання матеріалів періодичної печаті, ЗМI. Приклади проведення таких практикумів: «Завдання та ситуації 3 громадянського виховання в процесі вивчення соціо-гуманітарних дисциплін», «Активні методи в системі громадянського виховання».

Кураторські години у вищій школі - це спосіб спілкування викладача й студента, що наметі має вирішення низки виховних завдань, з-поміж яких важливе місце належить громадянському вихованню молоді. Викладачам можна запропонувати методичні рекомендації «Тематика кураторських годин із громадянського виховання студентської молоді».

Виховні заходи - це одна з форм залучення студентів до продуктивної діяльності, вони вирізняються масштабністю та числом учасників, 3-поміж яких $є$ як представники студентської молоді, так і члени громадських організацій, а також ті, для кого ці заходи проводяться. Наприклад: «Україна - європейська держава», «Я - громадянин української держави», «Найкраще - дітям» тощо.

Рефлексивний етап має завершальний характер, наметі має залучення молоді до самостійної роботи, самоаналізу й самовизначення. У межах цього етапу роботи 3 формування громадянськості найбільш дієвими є такі методи виховання: диспут, мозкова атака, створення та розв'язання проблемних ситуацій, проектна діяльність. Розкриємо зміст деяких із них.

Дискусія - основний метод, що лежить в основі проведення диспуту. Це колективне обговорення, дослідження проблеми, зіставлення інформації, ідей, пропозицій. Дискусія є ефективною тільки тоді, коли учасники відчувають інтерес до проблеми, обговорюваного питання. Визначають три стадії розвитку дискусії: на стадії орієнтації відбувається занурення у проблему, мотивація; на стадії оцінки здійснюється зіставлення або конфронтація ідей; на стадії консолідації виробляється колективне вирішення проблеми [4, с. 62]. Працюючи над проблемою формування громадянськості, студентам пропонуються такі теми для проведення дискусії: «Молодіжна політика держави: сучасні механізми реалізації», «Моє майбутнє в Україні», «Студентська молодь й політичні процеси», «Що таке демократія?».

Мозкова атака передбачає розподіл у часі основних етапів процесу вирішення проблеми, тобто етапів генерації ідей i ïx конструктивного опрацювання. Методика проведення мозкової атаки така: на початку роботи необхідно визначити дві підгрупи: генератори й аналітики відповідно до способу мислення. Другий етап - висування проблеми, активізації творчої діяльності. На етап генерації ідей відводиться не більше 20 хвилин, при цьому ведучий домагається стисливості та чіткості формулювань. Важливо, щоб усі ідеї фіксувалися та об'єктувалися. Завершується мозкова атака колективним підведенням підсумків і рефлексією [4, с. 78]. Для проведення мозкової атаки в навчальновиховному процесі ВНЗ студентам варто запропонувати такі проблемні теми: «Толерантність в системі полікультурного виховання молоді: механізми реалізації», «Волонтерська допомога дітям-сиротам» тощо.

Саме на рефлексивному етапі здійснюється позааудиторна громадська діяльність студентської молоді, участь у роботі органів студентського самоврядування, що позитивно впливає на формування громадянськості. 
Отже, визначена система виховної роботи з формування громадянськості студентської молоді у вищій школі повною мірою розкриває особливості й зміст технології громадянського виховання в навчально-виховному процесі вищого навчального закладу.

\section{Література}

1. Борищевський М. Громадянська спрямованість як міра соціальної відповідальності особистості / М. Борищевський // Педагогічна та психологічні науки в Україні. - К. : Педагогічна думка, 2007. - Т. 3. - С. 93-102. 2. Виховання громадянина : Сутність громадянського виховання [П. Ігнатенко, В. Поплужний, Н. Косарєва, Л. Крицька] // Шкільна бібліотека. - 2003. - №8. - С. 3 19. 3. Ортинський В. Педагогіка вищої школи : навч. посіб. [для студ.вищ.навч.закл.] / В. Ортинський. - К. : Центр учбової літератури, 2009. - 472 с. 4. Панфилова А. Инновационные педагогические технологии : Активное обучение : [учеб. пособие для студ. высш. учеб. заведений] / А. Панфилова. - М. : Издательский центр «Академия», 2009. - 192 с. 5. Сігова А. Педагогічні умови формування громадянської позиції студентської молоді : автореф. на здобуття наук. ступеня канд. пед. наук : спец. 13.00.07 «Теорія і методика виховання» / А. Сігова. - Луганськ, 2008. - 20 с. 6. Сопівник I. Формування громадянськості студентів вищих аграрних навчальних закладів : автореф. на здобуття наук. ступеня канд. пед. наук : спец. 13.00.07 «Теорія і методика виховання» / I. Сопівник. - Тернопіль, 2006. -22 с.

УДК 378:811.111(073)

О. В. Хоменко, кандидат пед. наук, доиент, Київський національний університет технологій та дизайну

\section{МОВА МІЖНАЦІОНАЛЬНОГО СПІЛКУВАННЯ ЯК ЕКОНОМІЧНА КАТЕГОРІЯ}

Хоменко О. В. Мова міжнаціонального спілкування як економічна категорія.

У статті йдеться про взаємовплив економіки та мови міжнаціонального спілкування у сучасному глобалізованому світі, про правомірність віднесення lingua franca до економічної категоріі.

Ключові слова: lingua franca, ідеологічна конвергенція, мовний бар’єр, економічна категорія.

Хоменко А. В. Язык межнационального общения как экономическая категория.

В статье речь идет о взаимовлиянии экономики и языка межнационального общения в современном глобализированном мире, о правомерности отнесения lingua franca к экономической категории.

Ключевые слова: lingua franca, идеологическая конвергенция, языковой барьер, экономическая категория.

Khomenko O. Lingua franca as the economic category.

The paper dwells on the reciprocal impact of economy and lingua franca in today's globalized world. Besides the author underscores the legitimacy of attributing the lingua franca to the economic category.

Key words: lingua franca, ideological convergence, language barriers, economic category.

Сучасний світ вступив в епоху глобалізації. Глобалізація в широкому значенні слова - це процес становлення єдиного світу [12]. За Стенлі Фішером (Stanley Fisher), глобалізація - не просто економічний феномен, вона полягає в поступовому формуванні єдиного економічного, інформаційного і культурного простору, «зменшуючи тим самим розміри земної кулі». Одним із найбільш помітних виявів глобалізації є ідеологічна конвергенція, тобто однакова оцінка переваг ринкового шляху розвитку економіки, інакше кажучи, досягнення «глобального однодумства» [6].

Ідеологічна конвергенція зумовлює усунення географічних, політичних та економічних бар'єрів. Натомість з'являється бар'єр мовний. Одним із чинників подолання його є, на нашу думку, становлення мови міжнаціонального спілкування (lingua franca) і оволодіння нею. Аналіз взаємовпливу lingua franca і глобалізованої економіки і $є$ метою нашої статті. 